\title{
South Korean Economic Miracle and Its Reflections in Los Angeles Times and New York Times, 1975-1979
}

\author{
Lee Young-gwan ${ }^{1}$ \\ ${ }^{1}$ Department of International Cultural Studies, Soonchunhyang University, Asan, Chungchungnamdo, Republic \\ of Korea \\ Correspondence: Lee Young-gwan, Department of International Cultural Studies, Soonchunhyang University, \\ Asan, Chungchungnamdo, Republic of Korea. Tel: 82-41-530-1160. E-mail: youngg59@sch.ac.kr
}

Received: February 9, $2012 \quad$ Accepted: March 17, $2012 \quad$ Published: June 1, 2012

doi:10.5539/ass.v8n7p91

URL: http://dx.doi.org/10.5539/ass.v8n7p91

This work was supported in part by the Soonchunhyang University Research Fund.

\begin{abstract}
The major characteristics of South Korea's economy had been set up during 1970s. The legacy of South Korea's economic development model was created during the last half of 1970s. The export-oriented economy became the major characteristics of South Korea's economy. Politically, the legacy of Park Chung-hee as a godfather figure developed the model led by a strong Presidential leadership. Economic initiatives introduced and carried out by a person not by the system. Socially, the sufficient distribution system of wealth was forced to be sacrificed for the economic development. The reports of Los Angeles Times and New York Times confirmed the facts. South Korea achieved its economic miracle. The legacy was established in the 1970s especially the late half of the decade. Through the reports of those two major American newspapers a new image of South Korea was created while they provided vivid American views on South Korea's economic development of the period.
\end{abstract}

Keywords: economic miracle of Han River, South Korea, Park Chung-hee, Los Angeles Times, New York Times

\section{Introduction}

Under the leadership of Park Chung-hee, South Korea's GDP increased 452\% (1962-1980) and the total volume of exports skyrocketed from $\$ 10$ billion in 1964 to $\$ 1$ trillion in 1978. During the time, South Korea maintained an average of $8.5 \%$ increase of GDP and achieved the fastest economic development in the world (Kim, 2005). Among others including SOC, total labor in production also increased almost six times. The number of unemployment in 1960s reached 2 million, but Park's industrialization quickly absorbed the workers and middle class was slowly created during the late 1970s.

Even though Park limited democracy and political freedom for the sake of economic development, South Korea became one of the model countries for the economic development of the Third World. South Korea's economic development reached the peak during the year 1978 and it continued until the October of 1979. South Korea emerged as a full-pledged developing country at the second half of 1970s despite the world recessions and oil crises. In 1978 South Korea became a country of achieving economic miracle and the pace was faster than that of Japan.

This study aims to provide the American views on the South Korean economic miracle with the thorough examination of the reports from the Los Angeles Times and New York Times, two American major newspapers during this period. Unfortunately, Chicago Tribune did not deal with this subject for entire 1970s. Although they had some biased views, the views from outside on this matter would provide a true nature of South Korea's economic miracle of the late 1970s. While doing so, the positive and negative nature of South Korea's economy can be examined to clearly acknowledge what is the South Korean model of economic development.

\section{Continuation of the Export-Oriented Economy and Industrialization}

On March 9, 1975, a report in the Los Angeles Times expressed the concern for the possible set-back on the South Korean economy. It mentioned that Park Chung-hee's government predicted 7\% real growth in this year 
while many South Korean government officials expressed the doubt about attaining this goal. Nam Deuk-woo, Deputy Prime Minister and the head of the Economic Planning Board, described the difficulty to achieve $\$ 6$ billion export in this year. Since the U.S. estimated 1.5\% real growth and $4 \%$ for Japan, it would be very difficult for South Korea reaching this goal since $70 \%$ of South Korea's export targeted to these two countries. This uncertainty of the foreign markets and international economic condition, it was expected that South Korea's export-oriented economy would face the serious problems.

Although both Korean and foreign economists predicted that South Korea's long-term economic outlook remain bright, some foreign experts estimated that South Korea would be forced to borrow the capital more heavily abroad than it was anticipated. The nation's credit rating remained good with the International Monetary Fund (IMF) and foreign banks, but an U.S. diplomat pointed out that South Korea would have a tighter 1975 although the world economy would revive within a year.

If this report would prove to be true, it could be a near panic for South Korea. South Korea achieved $15 \%$ of real growth in the first half of 1974 despite the oil crisis of 1973 (Lee, 2011). Although the momentum of export was a halt in the second half of the year, South Korea ended with $8 \%$ real growth. Since the real growth rate of 1973 was a record $16.5 \%$, this trend of decrease would be a sign of losing momentum for the exports and it could be a beginning of a long-term stagnation. World economic stagnation suffocated markets for South Korea's three main exports - textiles, plywood and electronics - and factories had curtailed production drastically. Also, a foreign economist predicted that there would be about $10 \%$ of labor force in the industrial sector alone unemployed.

Domestic problems prevailed, too. The wholesale prices skyrocketed 44\% in 1974. A South Korean official optimistically stated that $7 \%$ real growth with $20 \%$ increase in wholesale prices would be a success according to this report. However, the currency devaluation of $20 \%$ of the Korean won last December would cause at least $10 \%$ increase of the price of imports. The devaluation forced the government to raise electricity rates by $42 \%$, freight rates by $39 \%$ and prices of petroleum products by $31 \%$.

The government planned tax cuts for low income families and $\$ 333$ million worth of subsidies for grain costs. Also, there would be a subsidy of $\$ 77$ million to lower fertilizer costs for famers. The government also prepared to provide $\$ 83$ million worth of fund for manufacturing firms and various public works projects were started to create jobs with the budget of $\$ 387$ million.

This report concluded that still the long-term perspective for South Korea's economy was not in serious trouble. For example, foreign investments continued to come. The plans to shift to greater concentration in heavy industry still were attracted many foreign investments. For example, Dow Chemical committed to invest $\$ 49$ million while Mitsui Chemical of Japan replaced Mitsubishi with $\$ 42.7$ million. The U.S. Steel Corp. soon would decide to invest on the construction of a steel mill in South Korea.

Year 1975 was not predicted as another successful year for the South Korea's economic development. The world economy was in the stage of stagnation and rapid development of the economy left many problems for South Korea domestically. At the same time, diplomatic difficulty with Japan caused the decline of Japanese investment that was crucial for the South Korea's economy.

On the other hand, Jameson (October 14, 1975) reported a positive forecast on South Korea's economy with the success story of Hyundai Auto Company. An interview with Chon Son-wai, Hyundai's marketing manager, its new subcompact car "Pony" planed to sale in the U.S. market in 1977. Hyundai expected to sell about 2,000 cars on a trial basis to two or three developing countries in Southeast Asia, Africa, or the Middle East in late 1976. According to Chon, Hyundai planned to export 30,000 units by 1979. South Korea's attempts to maintain its export-oriented economy continued with Hyundai Auto Company. It was the beginning of South Korea's exports from the cheap products with low technology to heavy industrial products.

On October 20, 1975, Jameson of the Los Angeles Times reported South Korea's President Park Chung-hee's new economic policy to "modernize the institutions of the Korean economy". Park declared a war against family owned conglomerates. Park forced them to go public and issue shares. Ultimately, the government would not allow any individual would own more than $30 \%$ of any company's stocks. This policy also aimed to vitalize the stock market while stripping the nation's big businessmen's potential political power. At the same time, President Park realized that Korea's economy needed a fundamental change for the further development at this point according to Jameson.

The incentives were provided including preferential corporate tax rate of $27 \%$ instead the $40 \%$ for unlisted firms. Already 157 firms had listed their stocks by May 1974. Through this measure, the government planned to 
increase stockholders up to 3.5 million, about one-tenth of the population by 1980 . During the U.S. military occupation of Japan after World War II, Japan carried out similar reform to removing Zaibatsu even though Jameson was not sure that South Korea would archive its goal like Japan did.

Jameson (October 27, 1975) reported again that South Korea archived a real growth of $7 \%$ despite many difficulties. In 1975, world economy declined as it mentioned before and South Korea suffered in its export. Also, South Vietnam fell and Kim Il-sung visited Beijing (Jameson, October 27, 1975). In these conditions, 7\% real growth was remarkable for him.

He pointed out that a timely implementation of government pump-priming in late 1974 successfully spurred the economy to a real $6.1 \%$ growth rate increase over the same period a year earlier. According to Jameson, the most crucial for the positive future was the assurance of about $\$ 2$ billion in foreign capital that needed to cover a current accounts deficit expected to exceed $\$ 1.8$ billion. This foreign capital was almost all in the form of loans. He added that there were good signs for the future, too such as the steady increase of the textile export.

After the interview with an U.S. embassy official in Seoul, Jameson pointed out that Washington assured the U.S. military commitment. In addition, diplomatic difficulties with Japan had been settled. The geo-political situation became stable for further economic development of South Korea. With those diplomatic assurance and improvements, a nine-nation aid consortium affirmed in a meeting in Paris its willingness to assist South Korea in obtaining \$2 billion worth of foreign capital each year for the next few years with low interests. Japan also agreed to provide as much as $\$ 500$ million to $\$ 600$ million a year from all private and governmental sources.

Another positive aspect was that while OPEC decided to raise oil price in $10 \%$ that could make South Korea pay additional \$120 million in 1976, Korea's rice production increased significantly and it made the government to save \$300 million in foreign currency. Among those positive features, Jameson did not forget to mention the fundamental problems that Seoul needed to overcome (Jameson, October 27, 1975). Inflation in wholesale prices reached $42 \%$ in 1974 and annual rate was around $25 \%$. Also, Seoul needed to manage the heavy deficit in international payments. Seoul tried to control the inflation with $17 \%$ devaluation last December, but it brought the concerns from outside. That is, it was not a permanent solution that the South Korean government could use to overcome the serious and continuous inflation.

Meanwhile, President Park Chung-hee decided to increase defense spending against growing military threats of North Korea. Park instituted a special defense tax. It included a $2.5 \%$ tax on imports, $10 \%$ to $30 \%$ surtax on incomes of individuals and corporations, and special assessments on virtually all consumer goods and services. Total defense budget reached \$1.5 billion in 1976 that was 4 times higher than that of 1972.

From Jameson's report, South Korea's economy was running well despite the world economic recession and high oil price. Still, he hesitated to thump up to consider South Korea would be a second Japan. The geo-political situation of Korean peninsula was not stable enough for the further development.

Also, heavy dependency on foreign capitals would cause problem for the future. At the same time, Seoul had very few tools to control the increasing inflation rate. He concluded the report with the warning that South Korea needed to diversify the foreign markets since $55 \%$ of its exports went to the United States and Japan while secure more loans from Europe.

Few days later, Jameson (October 31, 1975) introduced a key organization for the South Korea's economy to show American readers that South Korea's economy was in a good shape despite the problems. He considered that the Korean Development Institute (KDI) was a think tank and the core of an economic revolution which Park Chung-hee had been carried out. KDI was established in 1971 and at this time there were 180 staffs including 25 experts with Ph.D. mostly from prestigious American universities.

KDI was designing a blueprint to make South Korea economically self-sufficient by 1981. Achieving this goal, according to a KDI staff, Korea needed to maintain annual growth rate of $9 \%$ while emphasizing the social development and equity. It included the plans to increase the agricultural production and to seek for the measures to reduce the social and economic gaps between the urban and rural population. At the same time, another priority was the greater efficiency and the advancement of technology.

In this report, Jameson affirmed that KDI staffs were also worried about the inflation as he considered as a key barrier for the sustainable economic development. This report introduced the American readers that South Korea's economic development was well planned and Seoul would carry out its policy with a well discussed and carefully designed blueprint to achieve its goals while overcoming difficulties. For him, South Korea's economic success would continue despite the problems. 


\section{Economic Development and Social and Economic Readjustment}

On August 2, 1976, Jameson introduced a newly emerging middle class of South Korea with the interview with 34 years old Yoon Yong-kuk. His \$7,500-a-year income placed him close to the upper middle class in South Korea. 12 years ago, there was no middle class in South Korea. In 1975, 10\% to $15 \%$ of the population fell into the upper middle class with incomes of more than $\$ 8,500$ while majority of $60 \%$ to $65 \%$ were in the still predominant lower-class with incomes of less than $\$ 2,500$ a year.

Still, these figures were not clear to explain Korean social distinctions because one's social standing was determined by his/her family and educational background than by income at this time. According to Jameson (August 2, 1976), this traditional view was changing. With the rapid economic development, there were new opportunities for upward mobility in South Korea. Economic development was causing a social readjustment and this was what the South Korean government had to deal with for the sustainable development.

In the year 1976, South Korea introduced a new field of industry that would continue its export-oriented economy. Sam Jameson (August 18, 1976) reported that South Korea was virtually self-sufficient in fertilizer in 1976 and ready to export next year. This report explained the success story of the fertilizer industry in details. South Korea's fertilizer industry started construction in 1955. The U.S. aid was provided the loan to build the 85,000-ton-a-year urea plant in attempt to stop the yearly handouts of aid for importing fertilizer.

At the beginning, it was operated by the American officials that was resulted the inefficiency because of their political nature. As soon as South Korean management took over, the factory tripled production in three months. A band of talented engineering graduates of Seoul National University, who had received training in the United States and Switzerland, pulled off the feat.

A second urea plant, built with West German loans, went into operation in 1962 and by the middle of the year it debated a plan to double the production. The initial success persuaded American aid officials to back the next two fertilizer plants. American official loans covered $50 \%$ of the construction cost and Gulf Oil Corp. invested $\$ 10.6$ million in one of the plants. It was the first significant foreign investment in South Korea and proved to be a trail blazer, not only for the fertilizer industry but for the foreign investments in all sectors of the Korean economy.

For this project, U.S. aid provided loans totaling \$48.8 million and the Korea General Chemical Corp., a Korean government-owned firm, provided approximately $\$ 21$ million for the two projects. By the end of 1975 , the company accumulated assets worth $\$ 175$ million. The firm produced 2,066 million tons of fertilizer those were enough to provide the nation's farmers with all of the urea and compound fertilizer they needed. Overall, South Korea met $86 \%$ of its fertilizer needs at home.

This remarkable success story concluded with the concern for the long-term success of South Korean economy. First of all, Jameson pointed out that South Korea at this point was far less self-sufficient in food production. Although the production in food grains increased significantly, it was still not enough to feed the people. Also, number of famers decreased drastically from $80 \%$ in 1962 to $46 \%$ in 1975 . There was 2.2 -fold increase in per capita consumption of food grains over the last two decades led by economic growth. The per capita consumption of grains reached 671.4 pounds a year, of which 473 was produced at home.

Over production of fertilizer became a problem that forced South Korea to seek for the markets overseas. In 1977, one million-ton-a-year fertilizer plant to be built. With this new plant, South Korea would produce more than 3 million tons of fertilizer a year. In 1974, world fertilizer demands were so great and the price reached as much as $\$ 400$ a ton, but it had driven down to $\$ 120$ a ton for urea. Still, South Korea expected to earn at least $\$ 100$ million a year in export sales. It became another export-oriented industry, too.

South Korea's economy was successful enough that cause the social adjustment. Social mobility by the economic development created a new kind of middle classes for the first time in Korea. It was a beginning of the changes in the traditional social views in Korea. South Korea was not an agricultural and less developed country any more.

On January 30, 1977, Shim Jae Hoon of the New York Times reported that Seoul engaged in a new plan to continue its economic development. According to Shim, Seoul allocated $\$ 600$ million in foreign loans for facilities to support the booming export businesses. South Korea's economy grew impressively. After taking care of the inflation in 1976, South Korea's economic growth rate reached $15.2 \%$ that is about double the rate of 1975. It was the second highest in Korea's national history.

Per capital income reached $\$ 698$ that was $\$ 166$ higher than previous year and manufacturing went up 25.9\% while service industries grew up $11.3 \%$. Agriculture and fishery industries also grew up $8 \%$. According to Shim, 
South Korea was now moving from the stage of "taking-off" to a more sophisticated economic stage reminiscent of the development pattern of Japan.

In 1976, South Korea achieved almost $\$ 8$ billion in exports which was $49 \%$ higher than that of 1975 . It exceeded the government target by $24 \%$ increase. South Korea's payment deficits in oil reduced from $\$ 2$ billion in 1974 and 1975 to $\$ 400$ million in 1976. For the first time, South Korea secured sustainable foreign exchange reserves of $\$ 3$ billion.

Although the economic recovery in the United States and Japan credited this outstanding achievement, there were great efforts of the South Korean government. President Park visited factories personally to encourage workers to increase the productivities. More importantly, a New Five Year Plan successfully guided the annual economic growth of $10 \%$ while keeping inflation rate below $10 \%$. It also aimed to gain $\$ 10$ billion a year in exports.

The future of South Korea's economy was very bright to Shim. Even though Canadian and European Economic Community set new quotas on Korean products including textiles and electronics for $\$ 3$ billon in sale, South Korea could overcome the difficulties by seeking new markets in the Third World. Shim advised that Korean businessmen needed to invest on the development and sales for new and more sophisticated goods for the future.

Jameson of the Los Angeles Times also praised South Korea's economic success in his report (May 29, 1977). He said President Park Chung-hee became a "godfather" to the nation's businessmen. Jameson believed that hard working and low wages coupled with Park's authoritarian power had brought South Korea even closer to becoming one of the world's great trading nations.

His report described South Korea's economic success in detail again. Since 1960 South Korean exports had increased by $250 \% .1976$ alone exports rose by $56 \%$ to $\$ 7.7$ billion and the official goal for 1977 was an increase of $28 \%$ which would bring exports to $\$ 10$ billion. Seoul expected to have a trade surplus for the first time ever. Combined imports and exports were expected to exceed \$20 billion, a level achieved by Japan only 11 years ago.

In the year 1976, 14 South Korean firms exceeded $\$ 100$ million in exports and four exported more than $\$ 300$ million worth of products. In 1964, South Korean government dreamt of $\$ 100$ million worth of exports in national level. One of the most successful firms was Daewoo Industrial Co. that started with 5 employees ten years ago. In 1977, Daewoo had 22 companies with more than 35,000 people on the payroll, annual sales of $\$ 12$ billion and exports totaling $\$ 319$ million.

In this report, however, Jameson did not forget to point out the long-term difficulties of South Korea's economy. One of the South Korea's strength in the markets was price that came from the low labor costs. Compared to Taiwan and Hong Kong, white collar and skilled workers were paid $\$ 100$ a month while those two major competitors paid that of $\$ 400$. Even though many Korea workers maintained higher standard of discipline in order to prosper, South Korea would face the consequences soon.

There were no strikes, no minimum wage, no unemployment compensation, and no meaningful industrial safety regulations. Few significant labor unions were reliably reported and they were infiltrated by the Korean Central Intelligence Agency. Few labor riots had erupted but quickly suppressed and news of them had been censored out of the mass media.

The population growth exceeded the numbers of new jobs, therefore low labor costs would continue. However, without significant measures to improve the working condition in general, it would develop into a major socio-political problem for South Korea that would damage the export-oriented economy. Those domestic problems needed to be overcome. From this report, South Korea at this point needed to adopt a social security system for the sustainable economic development. It was another new task for Seoul to take care of.

At the same time, the success of South Korea would invite the restrictions overseas. Already in 1972, the United States imposed a limit of $7.5 \%$ on the growth of Korean textiles in the American market. Jameson believed that this success could mean trouble in the future internationally. Since IMF ranked South Korea as a developing country, many economic measures of the South Korea needed to follow the regulations of the international organizations. For example, South Korea's currency policy needed to meet the standard of developing country of IMF. Seoul could not maintain the policy of the protection for the domestic market as it used to. South Korea no longer enjoyed the protections internationally as a status of the less developed country.

Despite the criticism, Jameson believed that South Korea's success was remarkable and it would continue with some adjustment. Also, he pointed out that for the economic development, Korean people still had a faith on their government. The people's confidence on the government was very important for the further economic development as well as the authoritarian rule of President Park. 
In December, the New York Times (December 26, 1977) reported a significant development in South Korean economy. Seoul decided to open its financial market more to the outside. French Praisbas Bank opened its office in Seoul as the seventeenth foreign banks and eight more banks would come in 1978. Since South Korea became the top 20 trading nation of the world with commodity exports of $\$ 10$ billion in 1977, Seoul had the confidence to open its capital market and to diversify its financial market to ease the heavy dependencies on the U.S. and Japanese capitals.

This report pointed out that there were oppositions against this capital "open door" policy. Major criticism was that the government was moving too fast and too soon. For the Korean market, 26 foreign banks total about 20 along with representative offices were too much for the South Korea's financial capacity. At the same time, they were not representing Korea's interests.

Despite the oppositions, the government position was strong. The government assured that foreign banks would share less than $3 \%$ of total banking business like Japan. Also, with this development, Seoul would enjoy the increase of foreign reserves. It would discourage short-term dollar loans. In the long run, the government hoped to develop a foreign exchange market in Seoul. Until the end of fourth Five Year Plan that would end in 1981, South Korea needed about $\$ 2$ billion a year. Instead of going to Singapore and Tokyo to borrow money, the Korean government planned to copes to top resident banks in Seoul.

While foreign banks welcomed this new policy, local Korean banks were upset about this policy. They insisted that even before the opening, seventeen foreign branches lending \$245 million and it was a 7.9\% of total lending by five South Korean biggest commercial banks. They were worried about the growth rate of the market share of those foreign banks. Five years ago, foreign banks shared $2.2 \%$ and it increased to $5.6 \%$.

This development could not be change by the local Korean banks and criticism. Park Chung-hee decided to diversify the foreign dependence of capital. In the long run, Seoul was adopting globalized measure in finance. It also showed the world that South Korea behaved like one of the world top 20 trading nations.

South Korea's economic development was so successful at this point. There were less criticism and negative forecast on its future. At the same time, the economic growth forced Seoul to adopt new measures socially and financially. It was one of the most exciting periods with vitality in Korean history. This was the new image of Korea to the American readers that only knew Korea as the country devastated after the Korean War of 1950-1953.

\section{Miracle of Han River}

Still, many fundamental problems of South Korea's economy prevailed. One of them was the trade deficit with Japan. For the first half of 1978, the trade deficit with Japan reached \$1.5 billon. This figure was about \$200 million short of entire trade deficit for 1977. There was a growing concern that it might reach $\$ 3$ billion that was one quarter of South Korea's total exports volume. Since Japan supplied $70 \%$ of the raw materials for South Korea's textile, steel and petrochemical goods, Seoul blamed Tokyo blocking the import market with various tariffs and quota arrangements with South Korea (Shim, August 8, 1978).

Despite the difficulties, the Los Angeles Times reported the success story of Korean Air Line (KAL) on August 29, 1978 as a symbol of South Korea's success. It introduced that KAL became the second-ranked international air company among the 11 airlines in Asia in this year. In $1977 \mathrm{KAL}$ carried 2.5 million domestic and foreign passengers and transported some 62,000 tons of cargo. In cargo volume, KAL was seventeenth ranked in the world.

Jameson of the Los Angeles Times (July 3, 1978) reported the aftermath of the outstanding economic success of South Korea. According to him, South Korea was struggling to cool down its "red-hot" economy. Despite the government efforts, the economy appeared to be heated toward a real growth rate for the year of at least $13 \%$. That was about $3 \%$ more than the government had hoped for.

Construction and production levels were rising. Sales, wages, land prices and consumer prices were all soaring. An U.S. Embassy economist said, "Such a consumer revolution in Korea will come when gross national product hit \$1,000 per capita, and that was happening in this year" (Jameson, July 3, 1978).

For the third year in a row, wages had risen by $30 \%$ or more. A severe shortage of skilled workers had developed and workers were moving to new jobs paying double what they had been paid. From January through May, consumer prices rose $7.3 \%$, wholesale prices $5.9 \%$ and wholesale food prices $12.1 \%$. Land prices doubled in less than a year.

Still, South Korea was able to dodge the possible crisis. With the significant increase in export, Seoul secured 
excessive foreign incomes. In addition, many Korean construction firms won contracts for various projects in the Middle East. As a result Korean firms earned $\$ 880$ million in 1975 . It rose to $\$ 1.6$ billion in next year and $\$ 3$ billion in 1977. This trend continued in 1978.

The government stopped to borrow money from foreign banks to control inflation. At the same time, the government raised interest rates by $4.2 \%$ to $18.6 \%$ and loan rates were hiked $3 \%$ to $19 \%$. The Bank of Korea had stopped exchanging overseas dollar profits of Korean construction companies into won currency, forcing the firms to deposit overseas earnings in dollar accounts in Korean banks. The budget cuts of \$552.1 million had been ordered, too. Imports had been partially liberalized and price controls set on 150 items at the wholesale level. Although a government official predicted that it would take three months to a year to return to normal, Jameson thought that it was not that simple because South Korea's economic success would continue.

South Korea achieved the economic miracle. The success was more than what the government and its people as well as the world expected and predicted. Seoul reached its goal 2 years prior to its plan.

While South Korea suffered from the trade deficit with Japan, it enjoyed the surplus in the trade with the U.S. In 1978, South Korea's trade surplus with the U. S. was \$1.03 billion that was 53\% increase from that of 1977 (New York Times, January 31, 1979). Donald Ranard of the Los Angeles Times (February 27, 1979) insisted that Seoul's economic success had been accomplished at the expense of low-paid workers. Despite growing per-capita income statistics thousands of people were under sweatshop conditions without free unions. For him, South Korea's economic growth was extraordinary, but its cost in human terms had also been extraordinary.

On the other hand, George A. Geyer (May 7, 1979) of same newspaper emphasized that the U.S. needed to change its general perception on South Korea. He believed that South Korea was a country that worked because it worked, where streets burst with vitality. For him, South Korea was not just another country it was the American example of what could be done in a relatively free-enterprise Asiatic system.

A New York Times report (Freudenheim, August 26, 1979) also introduced the changing status of South Korea. According to this report, South Korea imported \$30 to \$40 million farm products from the United States during the Kennedy Administration, but now it increased to over $\$ 1$ billion. Even though South Korea still was classified as a developing country, it achieved annual growth of $10 \%$ in average for last 15 years and volumes of trade between these two countries reached $\$ 7$ billion per year. Although Henry Kissinger stated that the trade and foreign policy were not same, South Korea became a symbol of this change that the developing countries became more and more important to the United States economically that would affect on the U.S. foreign policy.

Jameson (July 22, 1979) again dealt with serious fundamental problems of South Korean economy. Overheated economy of real growth of $12.5 \%$ in 1975 was challenged with oil crisis. Many firms fired workers to cut costs. At the same time, the rise of oil price would provide additional inflationary pressure.

As Jameson predicted, inflation problem of South Korea continued in July 1979. The consumer price index at the end of May stood 30.8 points above the level of a year earlier and the wholesale price index had risen 22.9 points in a year. On an average annual basis, consumer prices in June rose 19.6\% and wholesale prices $16.3 \%$.

The announcement of raising oil prices by the OPEC would make the situation more serious for South Korea. The government artificially controlled to keep its domestic oil prices low. Finally, the government was forced to announce a price increase of average $59 \%$ on July 9 . It included the raise of electricity rates in $35 \%$.

Korean government officials had a confidence to overcome this trouble according to Jameson after the interviews with many South Korean officials. Still, he believed that this situation would cause serious social problem because of the lack of the healthy system of the distribution of wealth in South Korea as a World Bank report pointed out. Also, Seoul could slow down economic growth from $13 \%$ or more to $9 \%$ or $10 \%$ growth rate. The government would be happy with $7 \%$ or $8 \%$ rate of growth this year to control this problem. On the other hand it would cause possible multiple bankruptcies for Korean business groups. It was the dilemma of Seoul.

The New York Times also dealt with the South Korea's inflation problem. On August 23, 1979, Henry Strokes reported similar story that Jameson reported a month ago. Strokes pointed out that the $56 \%$ raise of gasoline prices made the gas station price more than $\$ 3$ per gallon. He believed that it would hurt Korean people who were already suffering from the inflation. There was a panic buying in Seoul. For instance, toilet papers were cleaned out from supermarket shelves within hours. While two million people were on summer vacation, but cut their spending $30 \%$ in average by day trips instead of overnight stays. He described South Korea's economy as an accordion. When the government squeeze the demand slackens over night.

Strokes mentioned that Koreans in general were optimistic on their future and the nation's economy. Some government officials said that a slight excess supply of products would correct the demand-supply balance. For 
Strokes, Korea's inflation was very peculiar in one aspect. It was not the result of the production cost rises, but by the desire of consumers to buy more. He added that the domestic saving since 1960 s went up $27 \%$ and economic growth of average $8 \%$ was achieved without excessive borrowing abroad. Also, the government budget was healthy in surplus. The raise of oil prices was not as serious as in the United States. Average Korean consumed oil one tenth of Americans and one fifth of Japanese.

Still, Strokes concluded his report with concerns. Unemployment rate reached to $4 \%$ by the end of June while it was 3.6\% last year. The government worried that it would go up. The government asked lower raises of pay for labor to take care of this problem, but it would be difficulty since the people were suffering from inflation.

In 1979, South Korea faced the major crisis. Inflation was not as severe as this incident. President Park Chung-hee was assassinated on October 26, 1979. Economic issues including inflation disappeared.

The "Miracle of Han River" suddenly stopped. Just after the assassination of Park Chung-hee, foreign investors were cautious but maintained the confidence on South Korea because of the smooth transition of political power. However, after the army takeover of power, the political instability damaged the South Korea's economy. Also, people lost the confidence, too. Even though Park was repressive authoritarian leader, his leadership in economic development was so important that it took a while to recover the dynamics and confidence of South Korea's economy.

\section{Conclusion}

South Korea today still maintains the export-oriented economy. 97\% of total GDP comes from export-related industries. The characteristics of South Korea's economy had been set up during the 1970s and still maintains. This is why the fairly objective views of American reports are so important to understand the South Korea's economy of 1970s as well as for the improvement of economic condition in the future. Some problems had been cured, but some still prevail.

Most of the reports pointed out that South Korea's economy of the last half of 1970s had some fundamental problems. First of all, South Korean government failed to develop the sound foundation for domestic market. Too much dependency on exports would cause long term problem. Also, there was a serious dependency on foreign capitals. As some reports predicted, South Korea experienced virtual collapse of economic system in 1997 because of that.

The North Korean threat still maintains although it's in different ways. Politically, the legacy of Park Chung-hee still remains. Most of the reporters failed to point out this, but even today South Korean government officials act with the president's remarks. That is, South Korea's technocrats lacked the attitude to direct the policy. Initiatives usually come from the presidential office. Socially, the lack of sufficient distribution system of wealth was pointed out by some reporters. Although there is fundamental limit to create the system satisfy all, the problem became more severe than ever since the adaptation of globalized economic system since 1997. Some fundamental problems need to be fixed for the future sustainable development that make South Korea became a developed country.

The true miracle was not the economic figures that South Korean people achieved, but their attitude and sprits ready for the challenges. Despite the continuous difficulties, South Korea became a developed country and the most of ranks related to the economic figures are within tenth in the world now. Maintaining this status, the problems need to be faced and overcome. Most importantly, as many American newspapers reports pointed out the hope and the spirits of South Korean people need to be remain.

\section{References}

Freudenheim, Milt. (1979, August 26). New Realities Shape Policy toward the Third World. New York Times, 141.

Geyer, George Anne. (1979, May 7). A Booming, Booming Country; Viewing South Korea's 'Miracle'. Los Angeles Times, p. C9.

Jameson, Sam. (1976, August 18). Fertilizer Plant Symbol of Korean Growth. Los Angeles Times, pp. D10-D11. -. (1975, October 27). Korea Gets Results from Pump-Priming' Economy Shows 7\% Gain Despite World Recession. Los Angeles Times, pp. D10-D11.

(1977, May 29). Korea Shaping Up As Great Trading Nation; Hard Work, Low Wages and Prodding by President Trigger Boom in Exports. Los Angeles Times, pp. L1-L2.

-------. (1975, October 14). Korea to Make Minicar, With U.S. Ultimate Goal. Los Angeles Times, pp. E8, E11. 
(1975, October 31). Korea's Park Encourages Think Tank; President Permits Free Debate at Institute, Listens to Staff. Los Angeles Times, pp. B1-B2.

-------. (1978, July 3). Red-Hot Economy Burns South Korea; Nation Not Ready for 'Explosion' of Consumer Boom. Los Angeles Times, Part IV, pp. 9-11.

-. (1979, July 22). S. Korea Economy on Firmer Footing to Battle Inflation. Los Angeles Times, pp. G11-G12.

------. (1975, October 20). S. Korea Firms to Go Public-by Force. Los Angeles Times, 11-12.

Kim, Hyung-A. (2005). Korea's Development Under Park Chung Hee: Rapid Industrialization, 1961-79, trans. Shin Myung-ju, (Seoul: Ilchokak).

Lee Young-gwan. (2011). American Views on South Korea's Economic Development in Los Angeles Times and New York Times, 1970-1974. Asian Social Science, 7(5), 85-97.

Ranard, Donald L. (1979, February 27). U.S.-China Ties Could Help Korea, But Peninsula's People Should Not Be Ignored in Their Struggle for Freedom. Los Angeles Times, p.C5.

Shim, Jae Hoon. (1978, August 8). Korea's Deficit Up with Japan. New York Times, p. D8. (1977, January 30). Korea Plans More Economic Gains. New York Times, p. IES 36.

Strokes, Henry S. (1979, December 22). Oil Cost Jolts Korean Economy. New York Times, 29.

Strokes, Henry S. (1979, August 23). Pressure Is on Seoul to Control Inflation. New York Times, pp. D1, D11.

(1975, March 9). After a Good Decade, S. Korea Faces a Year of Concern. Los Angeles Times, pp. G1-G2.

(1979, January 31). Korean Surplus in US Trade. New York Times, p. D3.

(1978, December 21). Seoul Raps Tokyo Inaction; Japan Trade Surplus Irks S. Korea. Los Angeles Times, p. E21.

(1977, December 26). South Korea, Returned to Health, Attracts Influx of Foreign Bankers. New York Times, 33.

(1978, September 29). Wings of Korea" becomes $2^{\text {nd }}$ Ranked World Airline in Asia. Los Angeles Times, p. I7. 